\title{
Peningkatan Hasil Belajar Matematika Materi Mengurutkan Bilanagn Melalui Model Pembelajaran Problem Based Learning
}

\author{
Widya Ayu Pratiwi \\ SD Negeri Pasucen 02 \\ pratiwiwwidyaayu@gmail.com
}

\section{Article History}

received 3/12/2020

\begin{abstract}
The purpose of this study was to determine the increase in student learning outcomes in the first semester of mathematics lessons in elementary school class I on the material of sorting numbers through the Problem Based Learning learning model. The subjects of this study were the first grade students of SD Negeri Pasucen 02 for the 2020/2021 academic year, totaling 26 students. The research conducted was classroom action research (CAR) consisting of two cycles, namely cycle I and cycle II. The stages of each cycle are planning, implementation, observation and reflection. Each cycle consists of two meetings. Data collection was obtained from the results of tests and observations. While the data analysis includes qualitative data and quantitative data. In the first cycle, the classical completeness was $61.84 \%$. While in the second cycle of $85,00 \%$. These results indicate that the Problem Based Learning model can improve the learning outcomes of class I students at SD Negeri Pasucen 02 in the content of learning mathematics in the matter of sorting numbers.
\end{abstract}

Keywords: learning outcomes, problem based learning learning model, mathematics

\begin{abstract}
Abstrak
Tujuan penelitian ini adalah untuk mengetahui peningkatan hasil belajar peserta didik pada muatan pelajaran matematika semester I di sekolah dasar kelas I pada materi mengurutkan bilangan melalui model pembelajaran Problem Based Learning. Subjek penelitian ini adalah peserta didik kelas I SD Negeri Pasucen 02 Tahun pelajaran 2020/2021 yang berjumlah 26 siswa. Penelitian yang dilakukan adalah penelitian tindakan kelas (PTK) terdiri dari dua siklus yaitu siklus I dan siklus II. Tahapan setiap siklusnya adalah perencanaan, pelaksanaan, observasi dan refleksi. Setiap siklus terdiri dari dua pertemuan. Pengumpulan data diperoleh dari hasil tes dan observasi. Sedangkan analisis data meliputi data kualitatif dan data kuantitatif. Pada siklus I ketuntasan klasikal sebesar $61,84 \%$. Sedangkan pada siklus II sebesar $85,00 \%$. Hasil ini menunjukkan bahwa model Problem Based Learning dapat meningkatkan hasil belajar peserta didik kelas I SD Negeri Pasucen 02 dalam muatan pembelajaran matematika materi mengurutkan bilangan.
\end{abstract}

Kata kunci: hasil belajar, model pembelajaran Problem Based Learning, matematika

Social, Humanities, and Education Studies (SHEs): Conference Series https://jurnal.uns.ac.id/shes 


\section{PENDAHULUAN}

Pendidikan bertujuan untuk menumbuh kembangkan potensi yang dimiliki peserta didik untuk bekal dalam menghadapi tantangan hidup di masa yang akan datang. Melalui pendidikan diharapkan mampu membentuk individu-individu yang berkompetensi di bidangnya sehingga sejalan dengan perkembangan ilmu pengetahuan dan teknologi (Rubiyanto, 2004: 1). Pendidikan akan membawa perubahan sikap, perilaku, dan nilai-nilai pada individu, kelompok dan masyarakat.

Pendidikan pada era sekarang lebih dikenal dengan istilah pembelajaran abad 21. Pembelajaran abad-21 pada proses pembelajarannya lebih mendorong peserta didik untuk mengembangkan kemampuan berpikir kreatif, yaitu proses berpikir yang tidak sekedar menghafal dan menyampaikan kembali informasi diketahui tetapi harus bisa berpikir tingkat tinggi (high order thinking skill) dengan memecahkan permasalahan dalam kehidupan sehari-hari terkait dengan materi dan menemukan jawaban sendiri sebagai pengalaman belajar.

Keberhasilan pembelajaran sangat bergantung pada kompetensi guru dan peserta didik. Pembelajaran akan lebih bermakna apabila menggunakan media dan model pembelajaran untuk mencapai tujuan. Guru harus memilih model pembelajaran yang tepat untuk mengajarkan suatu materi agar lebih mudah dipahami peserta didik. Terutama pada muatan pelajaran yang sering dianggap sulit oleh peserta didik, seperti muatan pelajaran matematika.

Penggunaan model pembelajaran harus sesuai dengan materi yang disampaikan, jika tidak sesuai maka tujuan pembelajaran yang diiginkan tidak akan tercapai. Hasil belajar matematika juga akan rendah karena peserta didik tidak memahami materi pelajaran yang disampaikan. Kasus rendahnya pemahaman peserta didik mengenai materi matematika masih banyak terjadi, seperti halnya di SD Negeri pasucen 02. Hasil belajar matematika kelas 1 pada materi pengelompokkan bilangan masih rendah, dari 26 peserta didik hanya 11 peserta didik $(40,00 \%)$ yang mendapat nilai di atas KKM sedangkan sisanya 15 peserta didik (60,00\%) mendapat nilai di bawah KKM 65. Berdasarkan data yang diperoleh tersebut maka perlu sekali dilaksanakan kegiatan pembelajaran yang inovatif untuk meningkatkan kualitas pembelajaran matematika terutama pada materi mengurutkan bilangan.

Berdasarkan hasil pengamatan dan refleksi, rendahnya hasil belajar matematika karena proses pembelajaran tidak memfokuskan pada peserta didik, tidak menyajikan masalah yang otentik dalam pembelajaran, peserta didik tidak membangun pengetahuannya sendiri melalui aktivitas belajar, proses pembelajaran tidak dilaksanakan dalam kelompok kecil, dan guru tidak berperan sebagai fasilitator. Selain itu guru belum menggunakan model dan media pembelajaran inovatif yang memberikan motivasi belajar pada peserta didik.

Peneliti melakukan alternatif tindakan untuk memperbaiki hasil belaar matematika dengan menerapkan model pembelajaran yang menarik, disesuaikan dengan karakteristik siswa dan materi pembelajaran serta tingkat perkembangan anak, yaitu model pembelajaran Problem Based Learning. Firmansyah dkk. (2015) mengatakan bahwa Problem Based Learning merupakan model pembelajaran yang memberikan kesempatan peserta didik menggali pengalaman autentik sehingga mendorong mereka aktif belajar, mengkonstruksi pengetahuan, dan mengintegrasikan konteks belajar di sekolah dan kehidupan nyata secara ilmiah. Peserta didik tidak sekedar mendengarkan, mencatat, dan menghafal materi yang disampaikan oleh guru, tetapi diharapkan mampu berfikir, mencari, mengolah data, dan berkomunikasi dalam proses pembelajaran.

Susilo dkk. (2012) mengatakan model pembelajaran Problem Based Learning hanya dapat terjadi jika guru mampu menciptakan lingkungan kelas yang terbuka dan membimbing pertukaran gagasan. Peran guru adalah sebagai pemberi rangsangan, 
pembimbing kegiatan peserta didik, dan penentu arah belajar yaitu suatu pola atau kerangka konseptual yang berisi prosedur sistematik dalam mengorganisasikan kegiatan pembelajaran untuk mencapai tujuan pembelajaran. Muhtadi, (2019: 22) Pembelajaran berbasis masalah meliputi penga-juan pertanyaan atau masalah, memusatkan pada keterkaitan antar disiplin, penyelidikan asli/ autentik, kerjasama dan menghasilkan karya serta peragaan Problem Based Learning mendorong peserta didik untuk belajar aktif dalam menggunakan konsep-konsep untuk memecahkan masalah. Peserta didik dapat memanfaatkan berbagai pengalaman yang telah dimilikinya untuk menemukan konsep baru berdasarkan penyelidikannya. Herlina dkk. (2016) menyimpulkan bahwa model pembelajaran Problem Based Learning berpengaruh secara signifikan terhadap hasil belajar peserta didik.

Problem Based Learning dapat digunakan dalam mencapai tujuan yang berkaitan dengan keterampilan pemecahan masalah yang berkaitan dengan mengurutkan bilangan. Berdasarkan pada permasalahan tersebut, dapat dirumuskan masalah, yaitu: apakah pene-rapan model Problem Based Learning dapat meningkatkan hasil belajar matematika materi mengurutkan bilangan pada peserta didik kelas $1 \mathrm{SD}$ Negeri Pasucen 02 ?. Adapun tujuan penelitian ini yaitu untuk mengetahui peningkatan hasil belajar peserta didik pada muatan pelajaran matematika di sekolah dasar kelas I pada materi mengurutkan bilangan melalui model pembelajaran Problem Based Learning.

\section{METODE}

Penelitian ini adalah penelitian tindakan kelas dengan menerapkan model pembelajaran Problem Based Leraning. Penelitian tindakan kelas ini terdiri dari empat tahapan dasar yaitu perencanaan (planning), pelaksanaan (acting), pengamatan (observing) dan refleksi (reflecting) dan dilaksanakan dalam II siklus. Setiap siklusnya dilaksanakan dalam 2 kali pertemuan. Penelitian ini dilaksanakan di SD Negeri Pasucen 02. Subjek penelitian ini adalah peserta didik kelas 1 Semester I tahun ajar 2020/2021 SD Negeri pasucen 02 berjumlah 26 peserta didik. Jumlah peserta didik laki-laki 18 dan peserta didik perempuan 8. Waktu penelitian berlangsung dari 25 Agustus 2020 sampai dengan 20 September 2020. Teknik pengumpulan data dengan teknik tes dan observasi. Teknik analisis data yang digunakan pada penelitian ini untuk mengolah dan menganalisis data hasil belajar peserta didik. Hal-hal yang dianalisis terkait dengan hasil belajar peserta didik adalah nilai hasil belajar siswa, rata-rata kelas, dan persentase tuntas belajar klasikal.

\section{HASIL DAN PEMBAHASAN}

Penerapan model pembelajaran Problem Based Learning pada siklus I diharapkan dapat meningkatkan kualitas pembelajaran matematika semester I tahun ajar 2020/2021 materi mengurutkan bilangan pada peserta didik kelas 1 SD Negeri Pasucen 02. Peningkatan hasil belajar tersebut ditunjukkan dengan meningkatnya nilai peserta didik saat mengerjakan soal tes tentang mengurutkan bilangan. Berikut ini akan disampaiakan hasil penelitian berupa data hasil belajar matematika melalui model pembelajaran Problem Based Learning pada peserta didik kelas 1 SD negeri Pasucen 02. Berdasarkan hasil tes formatif pembelajaran matematika pada siklus I melalui model pembelajaran Problem Based Learning pada peserta didik kelas 1 SD Negeri Pasucen 02, diperoleh data sebagai berikut:

Tabel 1. Hasil Belajar Peserta Didik Siklus I

\begin{tabular}{cccccc}
\hline No & Rentang Nilai & Frekuensi & Nilai & Persentase & Keterangan \\
\hline 1. & $88-100$ & 3 & 268 & $11,53 \%$ & Tuntas \\
2. & $76-88$ & 6 & 485 & $23,81 \%$ & Tuntas \\
3. & $65-76$ & 7 & 485 & $26,50 \%$ & Tuntas \\
\hline
\end{tabular}




\begin{tabular}{lcccc}
\hline $4 . \quad 10$ & 597 & $38.16 \%$ & $\begin{array}{c}\text { Tidak } \\
\text { Tuntas }\end{array}$ \\
Jumlah & & & & \\
Jumlah nilai total & 26 & 1.835 & $100 \%$ & \\
Nilai rata-rata & & 1.835 & & \\
Ketuntasan belajar klasikal & & 70,57 & & \\
Tidak tuntas & & $61,84 \%$ & & \\
\hline
\end{tabular}

Dari analisis data penelitian siklus I, diperoleh data berupa hasil belajar matematika materi mengurutkan bilangan pada peserta didik kelas 1 SD Negeri Pasucen 02 melalui model Problem Based Learning terjadi peningkatan. Siklus I sebanyak 16 $(61,84 \%)$ peserta didik yang sudah mendapatkan nilai di atas KKM, dan $10(38,16 \%)$ peserta didik yang nilainya masih di bawah KKM 65. Nilai rata-rata kelas pada siklus I yaitu sebesar 70,57 dengan nilai terendah 50 dan nilai tertinggi 90 . Ketuntasan klasikal pada siklus I sudah mengalami peningkatan tetapi belum maksimal yaitu $61,84 \%$. Ratarata nilai pada siklus I juga mengalami peningkatan dari sebelum menerapkan model pembelajaran Problem Based Learning yaitu mencapai nilai rata-rata 70,57 . Hasil belajar matematika pada peserta didik kelas 1 SD Negeri Pasucen 02 belum memenuhi kriteria indikator keberhasilan yang ditentukan yaitu minimal mencapai ketuntasan klasikal sebesar $80 \%$.

Berdasarkan refleksi pada siklus I maka diputuskan untuk melanjutkan ke siklus II dikarenakan belum mencapai ketuntasan klasikal yang diharapkan. Pada siklus II, diharap-kan dapat meningkatkan hasil belajar peserta didik pada pembelajaran matematika kelas I SD Negeri Pasucen 02 agar mencapai indikator keberhasilan yang ditetapkan dengan mem-bimbing peserta didik agar mempelajari materi dengan baik.

Berdasarkan hasil tes formatif pembelajaran matematika pada siklus II melalui model

pembelajaran Problem Based Learning pada peserta didik kelas 1 SD negeri pasucen 02, diperoleh data sebagai berikut:

Tabel 2. Hasil Belajar Peserta Didik Siklus II

\begin{tabular}{lccccc}
\hline No & Rentang Nilai & Frekuensi & Nilai & Persentase & Keterangan \\
\hline 1. & $88-100$ & 8 & 752 & $30,60 \%$ & Tuntas \\
2. & $76-88$ & 8 & 662 & $30,60 \%$ & Tuntas \\
3. & $65-76$ & 6 & 437 & $23,80 \%$ & Tuntas \\
4. & 565 & 4 & 225 & $15,00 \%$ & $\begin{array}{c}\text { Tidak } \\
\text { Tuntas }\end{array}$ \\
Jumlah & 26 & 2.076 & $100 \%$ & \\
Jumlah nilai total & & 2.076 & & \\
Nilai rata-rata & & 79,85 & & \\
Ketuntasan belajar klasikal & & $85,00 \%$ & & \\
Tidak tuntas & & $15,00 \%$ & & \\
\hline
\end{tabular}

Dari analisis data penelitian siklus II, diperoleh data berupa hasil belajar matematika pada peserta didik kelas 1 SD Negeri Pasucen 02 melalui model Problem Based Learning terjadi peningkatan dari siklus I. Hasil belajar matematika pada Siklus II sebanyak 22 (85\%) peserta didik yang sudah mendapatkan nilai di atas KKM, dan 4 (15 $\%)$ peserta didik yang nilainya masih di bawah KKM 65. Nilai rata-rata kelas pada siklus II juga mengalami peningkatan, pada siklus I yaitu sebesar 70,57 dengan nilai terendah 50 dan nilai tertinggi 90 menjadi nilai rata-rata pada siklus II sebesar 79,85 dengan nilai terendah 50 dan nilai tertinggi 100. Ketuntasan klasikal pada siklus II sudah memenuhi 
kriteria indikator keberhasilan yang ditentukan yaitu 85,00 \%. Hal ini membuktikan bahwa ada peningkatan hasil belajar peserta didik pada pembelajaran matematika setelah menerapkan model pembelajaran Problem Based Learning.

Hasil belajar merupakan perubahan tingkah laku yang relatif tetap yang diperoleh dari proses pembelajaran yang dilakukan secara sadar. Hasil belajar peserta didik diperoleh

dari kegiatan evaluasi dengan menggunakan tes pada akhir kegiatan pembelajaran atau tes formatif. Penerapan model Problem Based Learning dapat memberikan pembelajaran bermakna bagi peserta didik karena peserta didik berusaha mencari pemecahan masalah secara mandiri yang akan memberikan pengalaman nyata berdasar dari permasalahan yang muncul. Hal ini sesuai dengan pendapat Trianto (2011: 67), karena pengalaman itu memberikan makna tersendiri bagi peserta didik maka peserta didik dapat menggunakan pengalaman tersebut untuk memecahkan permasalahan yang serupa. Sehingga, jika satu permasalahan dapat disele-saikan oleh peserta didik, maka peserta didik dapat menggunakan cara yang sama apabila menemui permasalahan yang serupa.

\section{SIMPULAN}

Berdasarkan hasil penelitian dan pembahasan dapat disimpulkan bahwa: Penerapan model pembelajaran Problem Based Learning dalam pembelajaran matematika pada materi mengurutkan bilangan dapat meningkatkan hasil belajar peserta didik kelas 1 semester I tahun ajar 2020/2021 SD Negeri Pasucen 02. Hal tersebut ditunjukkan dengan ketuntasan klasikal pada siklus I sebesar 61,84\%, pada siklus II meningkat menjadi $85,00 \%$. Nilai rata-rata peserta didik juga mengalami peningkatan setiap siklusnya. Siklus I nilai rata-rata peserta didik 70,57 meningkat pada siklus II menadi 79,85. Peningkatan ini menunjukkan bahwa penerapan model pembelajaran Problem Based Learning dapat meningkatkan pembelaaran matematika. Dengan adanya penelitian tentang model pembelajaran Problem Based Learning, dapat membantu guru dalam menyelesaikan permasalahan tentang rendahnya hasil belajar matematika terutama pada materi mengurutkan bilangan.

\section{DAFTAR PUSTAKA}

Firmansyah, A., Kosim, \& Ayub, S. 2015. Pengaruh Model Pembelajaran Berbasis Masalah dengan Metode Eksperimen pada Materi Cahaya Terhadap Hasil Belajar Fisika Siswa Kelas VIII SMPN 2 Gunungsari Tahun Ajaran 2014/2015. Jurnal Pendidikan Fisika dan Teknologi, 1(3):154-159.

Herlina, Kasim, A., \& Mamu, H.D. 2016. Pengaruh Model Problem Based Learning dan Motivasi Berprestasi Terhadap Hasil Belajar Siswa Pada Mata Pelajaran Biologi di Kelas XI IPA MAN 2 Model Palu. Jurnal Sains dan Teknologi Tadulako, 5(1):1118.

Muhtadi, Ali. 2019. Pembelajaran Inovatif. Jakarta: Kementerian Pendidikan dan Kebudayaan.

Susilo, A.B., Wiyanto, \& Supartono. 2012. Model Pembelajaran IPA Berbasis Masalah untuk Meningkatkan Motivasi Belajar dan Berfikir Kritis Siswa SMP. Unnes Science Education Journal, 1(1):12-20.

Trianto. 2011. Model-model Pembelajaran Inovatif Berorientasi Konstruktivistik. Jakarta: Prestasi Pustaka. 